\title{
Optimal Nitrogen Management Enhanced External Chemical Nitrogen Fertilizer Recovery and Minimized Losses in Soil-Tomato System
}

\author{
Huimin Jiang ${ }^{1,2}$, Jianfeng Zhang ${ }^{1,2}$ \& Juncheng Yang ${ }^{1,2}$ \\ ${ }^{1}$ Institute of Agricultural Resources and Regional Planning, Chinese Academy of Agricultural Sciences, P. R. \\ China \\ ${ }^{2}$ National Engineering Laboratory for Improving Quality of Arable Land, Beijing, P. R. China \\ Correspondence: Juncheng Yang, Institute of Agricultural Resources and Regional Planning, Chinese Academy \\ of Agricultural Sciences, P. R. China. Tel: 86-10-8210-6203. E-mail: yangjuncheng@caas.cn
}

Received: December 20, 2014 Accepted: January 16, 2015 Online Published: February 15, 2015

doi:10.5539/jas.v7n3p179 URL: http://dx.doi.org/10.5539/jas.v7n3p179

\begin{abstract}
Excess chemical nitrogen $(\mathrm{N})$ fertilization is widespread in intensive greenhouse vegetable production in China and has resulted in low recovery efficiency and high losses of chemical $\mathrm{N}$ fertilizer. Understanding the fate of chemical $\mathrm{N}$ fertilizer is crucial for best management of chemical $\mathrm{N}$ fertilizer. Using the technique of stable isotope ${ }^{15} \mathrm{~N}$-labeled urea, a micro-plot experiment was conducted to estimate the recovery of ${ }^{15} \mathrm{~N}$-labeled urea in tomato, residues in soil and losses in soil-tomato system. The treatments included the conventional $\mathrm{N}$ management with chemical $\mathrm{N}$ rate $(1000 \mathrm{~kg} \mathrm{~N} / \mathrm{ha})$, named $\mathrm{FP}$ and optimal $\mathrm{N}$ management with chemical $\mathrm{N}$ rate $(500 \mathrm{~kg} \mathrm{~N} / \mathrm{ha})$, combined with maize straw and drip irrigation, named OPT. Compared with the FP, total dry matter yield increased by $6.5 \%-9.3 \%$ for the OPT in the autumn-winter season (AW) and winter-spring seasons (WS), respectively. There was a significantly higher recovery efficiency $(20.7 \%)$ of ${ }^{15} \mathrm{~N}$-labeled urea in the OPT compared to the FP $(11.3 \% ; P<0.05)$. The amount of residual $\mathrm{NO}_{3}^{-}-\mathrm{N}$ derived from ${ }^{15} \mathrm{~N}$-labeled urea was significantly higher in the FP than in the OPT $(P<0.05)$. More inorganic $\mathrm{N}$ derived from ${ }^{15} \mathrm{~N}$-labeled urea was incorporated into the stable fraction of organic matter in the OPT and had a positive effect on reducing the $\mathrm{N}$ leaching with increased time during the season. The loss rate of $\mathrm{N}$ derived from ${ }^{15} \mathrm{~N}$-labeled urea was $46.8 \%$ in the FP, $25.8 \%$ greater than in the OPT. Optimal $\mathrm{N}$ management improved tomato yields, enhanced chemical $\mathrm{N}$ recovery efficiency, while minimizing losses in the soil-tomato system. It will be practical for maintaining the sustainability of greenhouse-based intensive vegetable systems.
\end{abstract}

Keywords: ${ }^{15} \mathrm{~N}$-labeled urea, greenhouse vegetable production, soil $\mathrm{NO}_{3}{ }^{-}-\mathrm{N}$ accumulation, $\mathrm{N}$ recovery efficiency

\section{Introduction}

Greenhouse vegetable production plays an important role in China with 3.5 million hectares under greenhouse vegetables and this hectare increases annually by $10 \%$ (Guo et al., 2012). In Shouguang, Shandong Province, one of the most important vegetable production areas, more than $65.0 \%$ of the arable land is used for intensive greenhouse production (Song et al., 2009).

High chemical $\mathrm{N}$ fertilization is a common practice by farmers in the management method of greenhouse vegetable production to ensure high yields. Seasonal average $\mathrm{N}$ input by chemical fertilizer increased during 1994-2004 from 817 to $1178 \mathrm{~kg} \mathrm{~N} / \mathrm{ha}$ in Shouguang (He, 2006), which was 3-5 times more than vegetables required (Song et al., 2012). Consequently, the recovery efficiency of chemical $\mathrm{N}$ fertilizer is typically $<15 \%$; for example only $10 \%$ of applied $\mathrm{N}$ was taken up by vegetables (Chen et al., 2004; Du, 2005), indicating that most applied chemical fertilizer was either washed out of the root zone or lost to the atmosphere and groundwater by different pathways (Min et al., 2011).

Currently, furrow irrigation is dominant in major greenhouse vegetable production areas in China. Cumulative irrigation water ranged from to 748 to $1957 \mathrm{~mm}$ annually, with an of average $1307 \mathrm{~mm}$ in Shouguang, which was far more than crop needs or soil water-holding capacity (Song, 2007). Appropriate irrigation management is essential for maximizing crop yield, fertilizer and water use efficiency for vegetable production. Drip irrigation combined with optimized fertilization could accurately control the timing and amount of irrigation and reduce fertilizer losses (Tanaskovik et al., 2011; Fan et al., 2014). 
Soil organic matter is one of the important components of soil, and has a significant role in greenhouse vegetable production. It is widely believed that below $20 \mathrm{~g} / \mathrm{kg}$ soil organic carbon (C) will decline soil quality (Loveland \& Webb, 2003). Lei et al. (2010) showed that soil organic C was only $11.4 \mathrm{~g} / \mathrm{kg}$ in intensively used vegetable greenhouses in North China. Intensive use, high temperature and humidity accelerated the mineralization of soil organic matter, preventing necessary accumulation (Grandy \& Robertson, 2007). Application of plant residues with a high $\mathrm{C}: \mathrm{N}$ ratio (e.g. maize straw) may counterbalance the effects of mineralization. However, drip irrigation combined with maize straw method has seldom been studied in intensive production systems for greenhouse vegetables.

To achieve sustainable vegetable production and environmentally safe agriculture, a consecutive three-year field experiment was conducted to determine optimal chemical $\mathrm{N}$ management method in an intensive greenhouse vegetable system in Shouguang. Different $\mathrm{N}$ fertilizer management methods were incorporated into the study and compared with the local farmers' conventional management. Combined with the analysis of agricultural, fertility and environment effects, the results demonstrated that $50 \%$ of the conventional chemical $\mathrm{N}$ rate, combined with maize straw and drip irrigation, was the optimal $\mathrm{N}$ chemical management method (Jiang et al., 2012, 2013). However, there is limited information concerning the total recovery of applied chemical $\mathrm{N}$ fertilizer in the soil-tomato system and the residual effect of chemical $\mathrm{N}$ fertilizer on tomatoes during subsequent growing seasons in greenhouses. Thus, the main objectives of the present study are to (1) quantify the proportion of ${ }^{15} \mathrm{~N}$-labeled urea taken up by the different parts of tomato; (2) provide information on recovery of ${ }^{15} \mathrm{~N}$-labeled urea in the soil-tomato system; and (3) evaluate the availability of residual ${ }^{15} \mathrm{~N}$-labeled urea to the subsequent crop. The results would also show why the optimal chemical N management could achieve sustainable vegetable production and environmentally safe agriculture.

\section{Materials and Methods}

\subsection{Experimental Site}

A micro-plot experiment was conducted from September 2009 to July 2010 in Daotian $\left(36^{\circ} 49^{\prime} 57.7^{\prime \prime} \mathrm{N}\right.$, $118^{\circ} 54^{\prime} 58.9^{\prime \prime}$, a town in Shouguang, Shandong Province, China) - a representative region of intensive greenhouse production. The mean annual evapotranspiration is $1345.7 \mathrm{~mm}$ and the annual precipitation is 550 $\mathrm{mm}$. The frost-free period is $200 \mathrm{~d}$. The internal temperatures of greenhouses used for vegetable production are in the range of $12-45^{\circ} \mathrm{C}$ annually, with a mean of $25^{\circ} \mathrm{C}$. The soil texture is $36.0 \%$ sand $(2-0.05 \mathrm{~mm}), 61.0 \%$ silt $(0.05-0.002 \mathrm{~mm})$ and $3.0 \%$ clay $(<0.002 \mathrm{~mm})$ (Song et al., 2009). The region is characterized as coastal alluvial plain, and the elevation does not exceed $50 \mathrm{~m}$. There is no obvious soil acidification.

\subsection{Experimental Design}

Treatments consisted of two successive growing seasons, for the autumn-winter (AW) season, transplanting occurred in September and the final harvest was in February of the following year. For the winter-spring (WS) season, transplanting was in March and the final harvest in July of the same year. The greenhouse used in the present study had been used for vegetable cultivation for eight years before the field experiment site was established. The soil fertility was at the mid- to high-yield levels with a high fertilizer application rate (Lu, 2000). Soil organic matter and total $\mathrm{N}$ concentration in the $0-20 \mathrm{~cm}$ soil profile were 14.0 and $1.35 \mathrm{~g} / \mathrm{kg}$, respectively. Other soil chemical properties were as shown in Table 1.

Table 1. Chemical and physical properties in $0-20 \mathrm{~cm}$ soil layer

\begin{tabular}{llllll}
\hline Organic matter $(\mathrm{g} / \mathrm{kg})$ & Total N $(\mathrm{g} / \mathrm{kg})$ & $\mathrm{NO}_{3}-\mathrm{N}(\mathrm{mg} / \mathrm{kg})$ & Olsen-P $(\mathrm{mg} / \mathrm{kg})$ & Available K $(\mathrm{mg} / \mathrm{kg})$ & $\mathrm{pH}$ \\
\hline 14.0 & 1.35 & 73.3 & 138.5 & 584.4 & 7.7 \\
\hline
\end{tabular}

There were two treatments, with three replicates each, laid out in a completely randomized design. The two treatments were as follows: $100 \%$ of conventional chemical N rate (FP, $1000 \mathrm{~kg} \mathrm{~N} / \mathrm{ha}$ ) and $50 \%$ of FP combined with maize straw and drip irrigation (OPT). A survey to $\mathrm{N}$ management practices in the greenhouse-based vegetable production system of Shouguang was conducted in 127 farms in July 2007 (Figure 1). Based on the results of the survey, local farmers' conventional fertilizer rates were established (Table 2). Optimal N management method was determined using a consecutive three-year field experiment (Jiang et al., 2012, 2013). The ${ }^{15} \mathrm{~N}$-labeled micro-plot area (made of corrosion resistant plate of $100 \mathrm{~cm}$ length, $75 \mathrm{~cm}$ width and $110 \mathrm{~cm}$ height) was $0.75 \mathrm{~m}^{2}$. Micro-plots were pushed into the soil in early August 2009. About $10 \mathrm{~cm}$ of each micro-plot was left above the soil surface to prevent soil runoff entering the micro-plot. The planting pattern in 
the greenhouse vegetable cropping system involved an initial transplantation of tomato, Solanum lycopersicum cv. Haoweisite, one of the primary cultivars in the local area. The distance between rows was $70 \mathrm{~cm}$ and the distance between plants was $40 \mathrm{~cm}$.
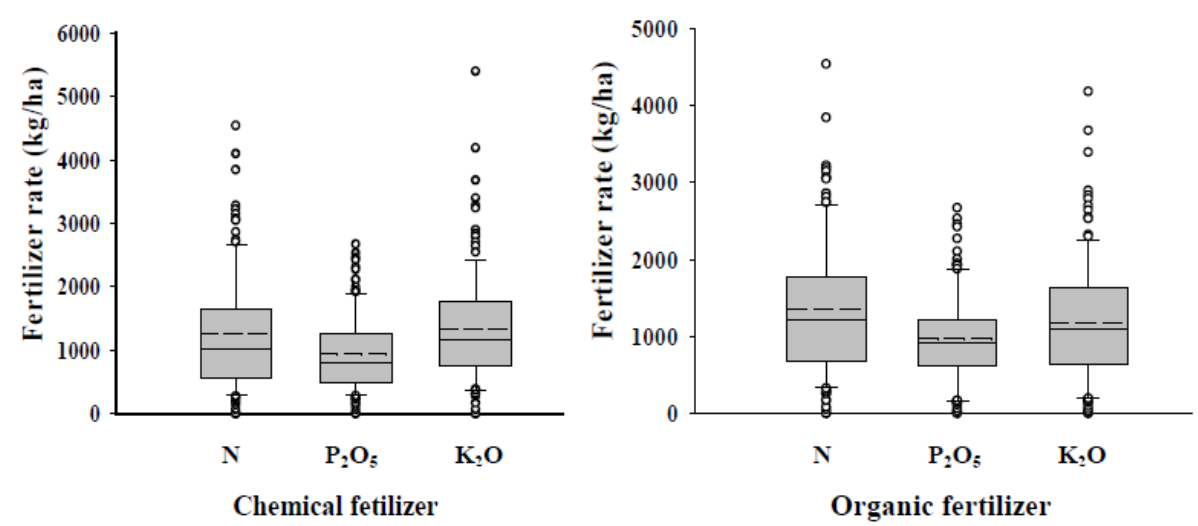

Figure 1. Variability of local farmers' conventional rates for application of chemical fertilizer and organic fertilizer. The boundary of the box closest to zero indicates the 25th percentile; the solid line within the box indicates the median; the broken line indicates the mean; the boundary of the box farthest from zero indicates the 75th percentile; error bars above and below the box indicate the 90th and 10th percentiles, respectively; and bullet points indicate the outliers

Table 2. Fertilization rates ${ }^{\mathrm{a})}$ in the micro-plot during the $\mathrm{AW}$ and $\mathrm{W}$ seasons

\begin{tabular}{|c|c|c|c|c|c|c|c|c|c|c|}
\hline \multirow{2}{*}{ Code } & \multirow{2}{*}{ Treatment } & \multicolumn{3}{|c|}{ Chemical fertilization } & \multicolumn{3}{|c|}{ Organic fertilization } & \multicolumn{3}{|c|}{ Total fertilization } \\
\hline & & $\mathrm{N}$ & $\mathrm{P}_{2} \mathrm{O}_{5}$ & $\mathrm{~K}_{2} \mathrm{O}$ & $\mathrm{N}$ & $\mathrm{P}_{2} \mathrm{O}_{5}$ & $\mathrm{~K}_{2} \mathrm{O}$ & $\mathrm{N}$ & $\mathrm{P}_{2} \mathrm{O}_{5}$ & $\mathrm{~K}_{2} \mathrm{O}$ \\
\hline & & \multicolumn{3}{|c|}{---- kg/ha season ${ }^{-1}$---- } & \multicolumn{6}{|c|}{ - } \\
\hline FP & $\begin{array}{l}100 \% \text { of conventional } \\
\text { chemical } \mathrm{N} \text { rate }\end{array}$ & 1000 & 800 & 1000 & 1200 & 976 & 1001 & 3200 & 2576 & 3001 \\
\hline OPT & $\begin{array}{l}50 \% \text { of } \mathrm{FP}+\text { maize straw } \\
+ \text { drip irrigation }\end{array}$ & 500 & 800 & 1000 & 1200 & 976 & 1001 & 2200 & 2576 & 3001 \\
\hline
\end{tabular}

Note. ${ }^{\text {a) }}$ Chemical fertilization was applied in both AW and WS seasons and organic fertilization was only in the $\mathrm{AW}$ season.

The fertilizer application was as follows in the AW season: $40 \%$ chemical $\mathrm{N}$ fertilizer $\left({ }^{15} \mathrm{~N}\right.$-labeled urea containing $46 \% \mathrm{~N}$, abundance $10.3 \%$, produced by the Institute of Chemical Industry in Shanghai, China), $100 \%$ chemical $\mathrm{P}$ fertilizer (calcium superphosphate containing $12 \% \mathrm{P}_{2} \mathrm{O}_{5}$ ), $40 \%$ chemical $\mathrm{K}$ fertilizer (potassium sulfate containing $60 \% \mathrm{~K}_{2} \mathrm{O}$ ) and $100 \%$ organic fertilizer (commercial organic fertilizer containing $1.86 \% \mathrm{~N}$, $3.11 \% \mathrm{P}_{2} \mathrm{O}_{5}$ and $0.85 \% \mathrm{~K}_{2} \mathrm{O}$ ) were applied for the basal dressing. The other $60 \%$ chemical $\mathrm{N}$ and chemical $\mathrm{K}$ fertilizers were applied as top-dressing. Thereafter, based on physiological needs and plant growth, four additional chemical fertilizers were applied during flowering and fruiting stages. Dry maize straw $(0.98 \% \mathrm{~N}$, $0.625 \mathrm{P}_{2} \mathrm{O}_{5}, 1.05 \% \mathrm{~K}_{2} \mathrm{O}$ and C:N of 49) was cut to lengths of $1.5 \mathrm{~cm}$ and applied at $7500 \mathrm{~kg} / \mathrm{ha}$ as a basal dressing in the OPT treatment. During the WS season in 2010, the basal fertilizer of chemical N fertilizer (no ${ }^{15} \mathrm{~N}$-labeled urea containing $46 \% \mathrm{~N}$ ) and chemical $\mathrm{K}$ fertilizer (potassium sulfate containing $60 \% \mathrm{~K}_{2} \mathrm{O}$ ) accounted for $20 \%$ of total fertilizer application, and chemical P fertilizer (calcium superphosphate containing 12 $\% \mathrm{P}_{2} \mathrm{O}_{5}$ ) accounted for $100 \%$. The other $80 \%$ of $\mathrm{N}$ and $\mathrm{K}$ fertilizers were applied during flowering and fruiting stages.

Each treatment plot was irrigated separately. Furrow irrigation was used in the FP treatment. The drip system of the OPT treatment consisted of polyethylene laterals of $12 \mathrm{~mm}$ in diameter, laid parallel to the crop row with each lateral serving one row of crop. In the AW season, irrigation was applied a total of eight times, applying 626 and $410 \mathrm{~mm}$ in the FP and OPT treatments, respectively; correspondingly, in the WS season, irrigation was applied nine times, applying 728 and $520 \mathrm{~mm}$. 


\subsection{Soil and Plant Sampling}

Five soil core samples were collected from each micro-plot after harvesting and combined to give composite samples, sectioned into 0-20, 20-40, 40-60, 60-80 and 80-100 cm depth increments. Each soil sample was then separated into two subsamples. One was air dried and stored at room temperature prior to the determination of total $\mathrm{N}$ and ${ }^{15} \mathrm{~N}$ enrichment. The other part was used to determine moisture content and sealed, stored at $4{ }^{\circ} \mathrm{C}$ and analyzed for the content of soil mineral $\mathrm{N}$ and mineral ${ }^{15} \mathrm{~N}$ enrichment.

In each growing season there were 7-11 harvests. Plant shoot and fruit samples were taken from each micro-plot on each harvest date for determination of fresh and dry weights. All samples from the same plot were broken up and mixed for total $\mathrm{N}$ determination. To simulate commercial practice, the plants were pulled from the soil at the final harvest and some roots remained in the soil. Plant samples were taken from each plot after harvesting, chopped, mixed and weighed before and after drying at $75^{\circ} \mathrm{C}$ for $48 \mathrm{~h}$.

\subsection{Chemical Analysis and Methods}

Soil and water were mixed at a ratio of 1:2.5 and a glass electrode was used to measure soil $\mathrm{pH}$ (Lu, 2000). Analyses of available nutrients in the soil included measurements for soil available P (Olsen et al., 1954), and K (Pratt, 1951). Fresh soil samples were extracted with $100 \mathrm{ml}$ of $2 \mathrm{M} \mathrm{KCl}$ for $1 \mathrm{~h}$ in a 1:5 (w/v) ratio, and then the extract was distilled to include both $\mathrm{NH}_{4}{ }^{+}-\mathrm{N}$ and $\mathrm{NO}_{3}{ }^{-} \mathrm{N}$ as total mineral $\mathrm{N}$ (Ju et al., 2002). The total $\mathrm{N}$ content of soil and plants were determined using the Kjeldahl determination method (Bao, 2000). The ${ }^{15} \mathrm{~N}$ abundance in soil and plant samples was measured by a modified ZHT-03 mass spectrometer at $0.1 \%$ accuracy (Schindler \& Knighton, 1999).

\subsection{Ammonia Volatilization}

An instrument was designed to collect $\mathrm{NH}_{3}$ volatilized from the soil surface during the $\mathrm{AW}$ season in 2009. Two pieces of sponge were immersed in $15 \mathrm{ml}$ of glycerol phosphoric acid $(50 \mathrm{ml}$ of phosphoric acid and $40 \mathrm{ml}$ of glycerol) before installation in a PVC cylinder $15 \mathrm{~cm}$ in diameter and $10 \mathrm{~cm}$ high (Figure 2). The base of the cylinder was inserted $1 \mathrm{~cm}$ into the soil. The lower sponge absorbed $\mathrm{NH}_{3}$ volatilized from the soil surface in the cylinder and the upper sponge absorbed $\mathrm{NH}_{3}$ from outside the cylinder and prevented its absorption by the lower sponge. The instrument was installed immediately after fertilizer application or irrigation. The lower sponge was replaced with new one after $24 \mathrm{~h}$ and the upper sponge was changed every 3 days. The sponges were taken to the laboratory and extracted with $300 \mathrm{ml}$ of $1 \mathrm{M} \mathrm{KCl}$ for $30 \mathrm{~min}$. About $500 \mathrm{ml}$ of equilibrium liquid was sampled and stored frozen before analysis (Wang et al., 2004).

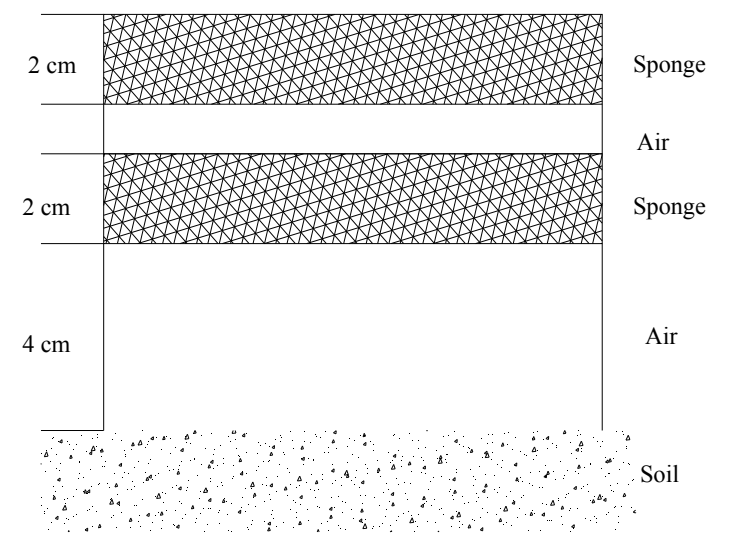

Figure 2. Sketch of ammonia absorption equipment in ${ }^{15} \mathrm{~N}$-labeled urea micro-plot

\subsection{Calculation and Statistical Analysis}

The principal method of analysis of stable isotopes is mass spectrometry. Abundance, also called natural abundance, of an element is the percentage of the number of atoms in the stable nuclide divided by the total number of atoms of the element. The difference between the abundance of the stable nuclide and the natural abundance is the atom percent excess of the element, which is also called enrichment (Zhang et al., 2012).

The percentages of plant $\mathrm{N}$ derived from fertilizer and soil were calculated by the following equations (Malhi et al., 2004): 


$$
\begin{gathered}
\% N d f=\left(\text { atom } \%{ }^{15} \mathrm{~N} \text { excess of total } N \text { in plant }\right) /\left(\text { atom } \%{ }^{15} \mathrm{~N} \text { excess of total } N \text { in fertilizer }\right) \times 100( \\
\% N d f_{S}=100-\% N d f f \\
N d f f(\mathrm{~kg} / \mathrm{ha})=\% N d f f \times T N \\
N d f s(\mathrm{~kg} / \mathrm{ha})=T N-N d f f
\end{gathered}
$$

Where $\% \mathrm{Ndff}$ is the percentage of total $\mathrm{N}$ in fruit or shoot derived from the ${ }^{15} \mathrm{~N}$-labeled urea, and the weighted mean was calculated to determine $\% \mathrm{Ndff}$ in the whole plant. Where atom $\%{ }^{15} \mathrm{~N}$ excess of total $\mathrm{N}$ in plant $=$ (atom $\%{ }^{15} \mathrm{~N}$ excess of total $\mathrm{N}$ in plant of fertilized plot) - (atom $\%{ }^{15} \mathrm{~N}$ excess of total $\mathrm{N}$ in plant in unlabeled fertilizer plot), and atom $\%{ }^{15} \mathrm{~N}$ excess of total $\mathrm{N}$ in fertilizer $=\left(\right.$ atom $\%{ }^{15} \mathrm{~N}$ abundance of fertilizer $)-\left(\right.$ atom $\%{ }^{15} \mathrm{~N}$ abundance of atmosphere $(0.37 \%)$ ). $\% \mathrm{Ndfs}$ is the percentage of $\mathrm{N}$ from soil. We calculated the total $\mathrm{N}$ in the plant tissue derived from the ${ }^{15} \mathrm{~N}$-labeled urea, $\mathrm{Ndff}(\mathrm{kg} / \mathrm{ha})$; and the total $\mathrm{N}$ in the plant tissue derived from the soil, $\mathrm{Ndfs}(\mathrm{kg} / \mathrm{ha})$. TN is the total $\mathrm{N}$ of ${ }^{15} \mathrm{~N}$-labeled urea taken up in the plant part, $\mathrm{kg} / \mathrm{ha}$.

The percentage of recovery of ${ }^{15} \mathrm{~N}$-labeled urea in the plant parts or remaining in the soil at the end of crop growing season by the isotopic method was calculated using Equation 5 (Bronson et al., 2000):

$$
R E N(\%)=(T N \times \% N d f f) / F \times 100
$$

Where REN is recovery efficiency of applied ${ }^{15} \mathrm{~N}$-labeled urea in plant or remaining in the soil $\mathrm{N}$ pool and $\mathrm{F}$ is the rate of ${ }^{15} \mathrm{~N}$-labeled urea applied $(\mathrm{kg} / \mathrm{ha})$.

The ammonia volatilization rate was calculated using Equation 6 (Xu et al., 2013):

$$
R_{A V}=M /(A \times D) \times 10^{-2}
$$

Where $R_{A V}$ is the ammonia volatilization rate $(\mathrm{kg} \mathrm{N} /($ ha d)), $\mathrm{M}$ is the amount of ammonia $\mathrm{N}$ collected by the PVC collector (in $\mathrm{mg}$ ), A is the cross-sectional area of the PVC collector (in $\mathrm{m}^{2}$ ) and D is the interval for ammonia volatilization sample collection (in days).

The results were subjected to analysis of variance (ANOVA) to determine whether the differences among data were significant (means \pm standard errors, $\mathrm{n}=3$ ). The analysis was performed using SAS 8.0 for Windows software package (SAS Inc., 1999). The least significant difference (LSD) was used to determine differences between individual treatments. All tests were conducted at a significance level of $P<0.05$. Graphics were prepared using the Origin 8.0 and SigmaPlot 10.0 software programs.

\section{Results}

\subsection{Crop Dry Matter and N Uptake from ${ }^{15} \mathrm{~N}$-Labeled Urea by Different Parts of Tomato}

The higher chemical N fertilizer rate (FP) did not produce higher total dry matter yields (fruit + shoot). On the contrary, compared with the FP treatment, reducing 50\% chemical $\mathrm{N}$ fertilizer, combined with maize straw and drip irrigation, (i.e. OPT treatment), increased total dry matter by 6.5 and $9.3 \%$ in the AW and WS seasons, respectively (Table 3 ).

Plants take up $\mathrm{N}$ mainly from fertilizer $\mathrm{N}$ and soil $\mathrm{N}$. The $\mathrm{N}$ uptake from fertilizer $\mathrm{N}$ and soil $\mathrm{N}$ by tomato was 415.9 and $312.2 \mathrm{~kg} / \mathrm{ha}$ in the FP treatment for the AW and WS seasons, respectively, and correspondingly 445.5 and $331.3 \mathrm{~kg} / \mathrm{ha}$ in the OPT treatment. The results showed that more fertilizer $\mathrm{N}$ and soil $\mathrm{N}$ was taken up by tomato in the OPT than the FP treatment. The trace technique of using ${ }^{15} \mathrm{~N}$-labeled urea can be used to follow the sources of $\mathrm{N}$ uptake by a crop. In the AW season, for the conventional application rate of $1000 \mathrm{~kg} / \mathrm{ha}(\mathrm{FP})$, the percentage of total $\mathrm{N}$ uptake derived from the ${ }^{15} \mathrm{~N}$-labeled urea in tomato tissue was $23.1 \%$, and so the percentage of $\mathrm{N}$ from soil $\mathrm{N}$ was $76.9 \%$. For the lower $\mathrm{N}$ application of OPT, the percentage of total $\mathrm{N}$ uptake derived from ${ }^{15} \mathrm{~N}$-labeled urea in tomato tissue dropped to $19.3 \%$, and so the percentage derived from soil $\mathrm{N}$ reached $80.7 \%$. Similarly, $>75 \%$ of total $\mathrm{N}$ in the tomato was obtained from the soil $\mathrm{N}$ pool. Compared with the AW season, the percentage of total $\mathrm{N}$ uptake derived from ${ }^{15} \mathrm{~N}$-labeled urea was significantly lower in the WS season $(P<0.05)$. With the higher $\mathrm{N}$ application (i.e. FP treatment), the $\mathrm{N}$ uptake from urea by tomato in the OPT treatment dropped $10.2 \%$ in the AW season, but increased $6.0 \%$ in the WS season. The result indicated that more fertilizer $\mathrm{N}$ was utilized in the OPT treatment with the increased period of cultivation.

According to the $\mathrm{N}$ distribution pattern in different parts of tomato (Table 3), the $\mathrm{N}$ uptake was higher by tomato shoots than by fruit. In the FP treatment, $64.8 \%$ and $56.3 \%$ of total fertilizer $\mathrm{N}$ was taken up by shoots in AW and WS seasons, respectively; and correspondingly in the OPT treatment, $64.3 \%$ and $57.1 \%$. There was no significant difference between the FP and OPT treatments. 
Table 3. N uptake of ${ }^{15} \mathrm{~N}$-labeled urea by tomato

\begin{tabular}{|c|c|c|c|c|c|c|c|c|c|}
\hline \multirow[b]{2}{*}{ Tomato } & \multirow[b]{2}{*}{ Treatment } & \multicolumn{2}{|c|}{ Dry matter $(\mathrm{kg} / \mathrm{ha})$} & \multicolumn{2}{|c|}{$\mathrm{N}$ uptake (kg/ha) } & \multicolumn{2}{|c|}{ Ndff (kg/ha) } & \multicolumn{2}{|c|}{ Ndfs (kg/ha) } \\
\hline & & $\begin{array}{l}\mathrm{AW} \\
\text { season }\end{array}$ & $\begin{array}{l}\text { WS } \\
\text { season }\end{array}$ & $\begin{array}{l}\mathrm{AW} \\
\text { season }\end{array}$ & $\begin{array}{l}\text { WS } \\
\text { season }\end{array}$ & $\begin{array}{l}\text { AW } \\
\text { season }\end{array}$ & $\begin{array}{l}\text { WS } \\
\text { season }\end{array}$ & $\begin{array}{l}\text { AW } \\
\text { season }\end{array}$ & $\begin{array}{l}\text { WS } \\
\text { season }\end{array}$ \\
\hline \multirow[t]{2}{*}{ Fruit } & FP & $6867.7 \mathrm{a}$ & $5803.6 \mathrm{a}$ & $146.4 \mathrm{a}$ & $124.5 \mathrm{a}$ & $40.8 \mathrm{a}$ & $7.3 \mathrm{a}$ & $105.6 \mathrm{a}$ & $117.2 \mathrm{a}$ \\
\hline & OPT & $7151.4 \mathrm{a}$ & 5989.8 a & $158.9 \mathrm{a}$ & $123.6 \mathrm{a}$ & $37.7 \mathrm{a}$ & $7.6 \mathrm{a}$ & $121.2 \mathrm{a}$ & $117.0 \mathrm{a}$ \\
\hline \multirow[t]{2}{*}{ Shoot } & FP & $8390.9 \mathrm{a}$ & $8033.5 \mathrm{a}$ & $269.5 \mathrm{a}$ & $187.7 \mathrm{a}$ & $55.2 \mathrm{a}$ & $9.4 \mathrm{a}$ & $214.3 \mathrm{a}$ & $178.3 \mathrm{a}$ \\
\hline & OPT & $9061.2 \mathrm{a}$ & $9136.4 \mathrm{a}$ & $286.6 \mathrm{a}$ & $207.6 \mathrm{a}$ & $48.5 \mathrm{a}$ & $10.1 \mathrm{a}$ & $238.1 \mathrm{a}$ & $197.5 \mathrm{a}$ \\
\hline Total & FP & $15258.7 \mathrm{a}$ & $13837.1 \mathrm{a}$ & $415.9 \mathrm{a}$ & $312.2 \mathrm{a}$ & $96.0 \mathrm{a}$ & $16.7 \mathrm{a}$ & $319.9 \mathrm{a}$ & $295.5 \mathrm{a}$ \\
\hline biomass & OPT & $16212.6 \mathrm{a}$ & $15126.2 \mathrm{a}$ & $445.5 \mathrm{a}$ & $331.3 \mathrm{a}$ & $86.2 \mathrm{a}$ & $17.7 \mathrm{a}$ & $359.3 \mathrm{a}$ & $314.5 \mathrm{a}$ \\
\hline
\end{tabular}

Note. Figures followed by the same letter within a column for the same parts of tomato are not significantly different $(P<0.05)$ based on one-way ANOVA.

\subsection{Recovery of ${ }^{15} \mathrm{~N}$-Labeled Urea in a Soil-Tomato System}

In the AW season, the recovery efficiency of ${ }^{15} \mathrm{~N}$-labeled urea in tomato was $9.6 \%$ in the FP treatment (Table 4). The recovery efficiency of ${ }^{15} \mathrm{~N}$-labeled urea remaining in the $0-100 \mathrm{~cm}$ soil profile was $58.0 \%$. A total 676.2 $\mathrm{kg} / \mathrm{ha}$ of $\mathrm{N}$ remained in plant and soil, and the $\mathrm{N}$ recovery efficiency in the soil-tomato system was $67.6 \%$. The ${ }^{15} \mathrm{~N}$ not accounted for in the plant and soil was presumably lost, giving a loss rate of ${ }^{15} \mathrm{~N}$-labeled urea of $32.4 \%$. The amount of $\mathrm{N}$ recovered in the soil-tomato system decreased but the recovery efficiency increased when less chemical $\mathrm{N}$ fertilizer was used in the tomato field. When chemical $\mathrm{N}$ fertilizer application was reduced to 500 $\mathrm{kg} / \mathrm{ha}$ (OPT), N uptake by plants was also down to $86.2 \mathrm{~kg} / \mathrm{ha}$, but the recovery efficiency was slightly higher at $17.2 \%$. In the $0-100 \mathrm{~cm}$ soil profile, the residual $\mathrm{N}$ content was $372.6 \mathrm{~kg} / \mathrm{ha}$ representing a recovery efficiency of $74.6 \%$. The total plant and soil $\mathrm{N}$ recovery was $459.0 \mathrm{~kg} / \mathrm{ha}$, total $\mathrm{N}$ recovery efficiency was $91.8 \%$ and $\mathrm{N}$ loss rate was $8.2 \%$. In the WS season, the recovery efficiency in the soil-tomato system was significantly lower than in the AW season $(P<0.05)$. The $\mathrm{N}$ recovery efficiency was $11.2 \%$ and $37.4 \%$ in the FP and OPT treatments, respectively. There were higher $\mathrm{N}$ recovery efficiencies in tomato and soil in the OPT treatment, with accumulative recovery efficiency of applied ${ }^{15} \mathrm{~N}$-labeled urea in tomato in both seasons of $11.3 \%$ (FP) and $20.7 \%$ (OPT). Of all the ${ }^{15} \mathrm{~N}$-labeled urea absorbed by the tomato, $85.2 \%$ (FP) and $83.0 \%$ (OPT) accumulated in the AW season. After the two seasons, $9.6 \%$ and $33.8 \%$ of ${ }^{15} \mathrm{~N}$-labeled urea remained in the $0-100 \mathrm{~cm}$ soil profile under the FP and OPT treatments, respectively; and the corresponding $\mathrm{N}$ loss rates of applied ${ }^{15} \mathrm{~N}$-labeled urea were $79.2 \%$ and $45.4 \%$. More ${ }^{15} \mathrm{~N}$-labeled urea remained in the soil and there was a lower $\mathrm{N}$ loss rate in the OPT than in the FP treatment.

Table 4. Recovery and loss of ${ }^{15} \mathrm{~N}$-labeled urea in soil-tomato system at harvest time

\begin{tabular}{lllllllllll}
\hline Season & Treatment & $\begin{array}{l}\text { Recovery of } \\
{ }^{15} \mathrm{~N} \text { in tomato } \\
(\%)\end{array}$ & $\begin{array}{l}\text { Residual soil } \\
{ }^{15} \mathrm{~N}(0-100 \mathrm{~cm}) \\
(\mathrm{kg} / \mathrm{ha})\end{array}$ & $\begin{array}{l}\text { Residual } \\
\text { soil } \\
(\%)\end{array}$ & $\begin{array}{l}{ }^{15} \mathrm{~N} \\
\text { in tomato } \\
\text { soil }(\mathrm{kg} / \mathrm{ha})\end{array}$ & $\begin{array}{l}{ }^{15} \mathrm{~N} \\
\text { soil }(\%)\end{array}$ & $\begin{array}{l}\text { Recovery rate } \\
\text { in tomato and }\end{array}$ & $\begin{array}{l}\mathrm{N} \\
(\mathrm{kg} / \mathrm{ha})\end{array}$ & $\begin{array}{l}\mathrm{N} \text { loss rate } \\
(\%)\end{array}$ \\
\hline AW & FP & $9.6 \mathrm{~b}$ & $580.2 \mathrm{a}$ & $58.0 \mathrm{~b}$ & $676.2 \mathrm{a}$ & $67.6 \mathrm{~b}$ & $323.8 \mathrm{a}$ & $32.4 \mathrm{a}$ \\
season & OPT & $17.2 \mathrm{a}$ & $372.8 \mathrm{~b}$ & $74.6 \mathrm{a}$ & $459.0 \mathrm{~b}$ & $91.8 \mathrm{a}$ & $41.0 \mathrm{~b}$ & $8.2 \mathrm{~b}$ \\
WS & FP & $1.7 \mathrm{~b}$ & $95.6 \mathrm{~b}$ & $9.6 \mathrm{~b}$ & $112.3 \mathrm{~b}$ & $11.2 \mathrm{~b}$ & $467.9 \mathrm{a}$ & $46.8 \mathrm{a}$ \\
season & OPT & $3.5 \mathrm{a}$ & $169.2 \mathrm{a}$ & $33.8 \mathrm{a}$ & $186.8 \mathrm{a}$ & $37.4 \mathrm{a}$ & $186.0 \mathrm{~b}$ & $37.2 \mathrm{~b}$
\end{tabular}

Note. Figures followed by the same letter within a column for the same parts of tomato are not significantly different $(P<0.05)$ based on one-way ANOVA.

\subsection{Profile Distribution of the ${ }^{15} N$-Labeled Urea Residue in Soil}

A major proportion of the residual ${ }^{15} \mathrm{~N}$-labeled urea was enriched in the top $0-40 \mathrm{~cm}$ layer, and the $\mathrm{N}$ residue content was low in the deeper layers of soil in the AW season (Figure 3a). The surface $0-40 \mathrm{~cm}$ of soil contained $76.4 \%$ of the total residual $\mathrm{N}$ in the soil under the conventional $1000 \mathrm{~kg} / \mathrm{ha}$ fertilizer level. At the $500 \mathrm{~kg} / \mathrm{ha}$ 
fertilizer level, the $0-40 \mathrm{~cm}$ top layer of soil contained $86.9 \%$ of the total soil residual N. There was less accumulation of ${ }^{15} \mathrm{~N}$-labeled urea down to $40 \mathrm{~cm}$ in the OPT compared to the FP treatment. There were different trends in distribution of the ${ }^{15} \mathrm{~N}$-labeled urea residue in soil in the WS compared to the AW season. A major proportion of the residual ${ }^{15} \mathrm{~N}$-labeled urea was enriched in the top $40-100 \mathrm{~cm}$ surface layer in the FP treatment, containing $66.0 \%$ of the total residual $\mathrm{N}$ in soil - thus the leaching risk was increased (Figure $3 \mathrm{~b}$ ). In contrast, ${ }^{15} \mathrm{~N}$-labeled urea distributed in the $0-40 \mathrm{~cm}$ of the soil profile was significantly higher and the $\mathrm{N}$ residue content lower in the deeper layers of soil in the OPT compared to the FP treatment $(P<0.05)$.

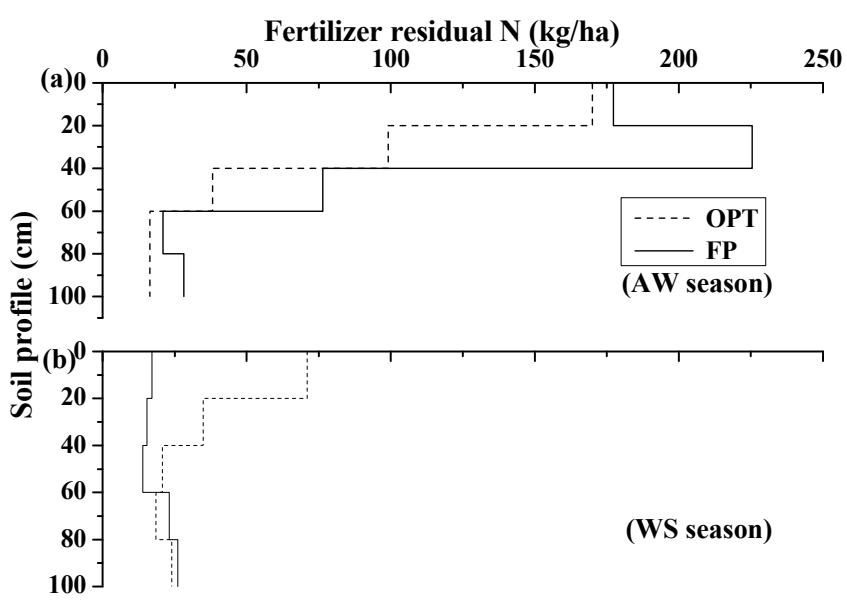

Figure 3. Distribution of ${ }^{15} \mathrm{~N}$-labeled urea residual in the soil profile $(0-100 \mathrm{~cm})$ for different treatments

Note. (a): AW season, (b): WS season.

$\mathrm{NO}_{3}{ }^{-} \mathrm{N}$ was the dominant form of soil mineral $\mathrm{N}$ derived from ${ }^{15} \mathrm{~N}$-labeled urea, and $\mathrm{NO}_{3}{ }^{-}-\mathrm{N}$ content decreased with increasing soil depth in the AW season (Figure 4a). The content of $\mathrm{NO}_{3}{ }^{-} \mathrm{N}$ accounted for $92.5 \%$ and $91.2 \%$ of the total soil residual $\mathrm{N}$ in the FP and OPT treatments, respectively. Application of the lesser amount of chemical $\mathrm{N}$ fertilizer, combined with maize straw and drip irrigation, resulted in markedly less $\mathrm{NO}_{3}{ }^{-}-\mathrm{N}$ accumulation in the same soil profile compared with the FP treatment $(P<0.05)$. The $\mathrm{NO}_{3}{ }^{-}-\mathrm{N}$ accumulation was mainly distributed throughout the $0-40 \mathrm{~cm}$ soil profile. The percentages of $\mathrm{NO}_{3}{ }^{-} \mathrm{N}$ accumulated were $75.8 \%$ and $81.9 \%$ in the FP and OPT treatments, respectively. In the WS season (Figure $4 \mathrm{~b}$ ), $\mathrm{NO}_{3}^{-}-\mathrm{N}_{\text {was }}$ also the dominant form of soil mineral $\mathrm{N}$ derived from ${ }^{15} \mathrm{~N}$-labeled urea in the FP treatment, accounting for $67.2 \%$; however, in the OPT treatment, soil organic $\mathrm{N}$ was the dominant form and accounted for $75.9 \%$.

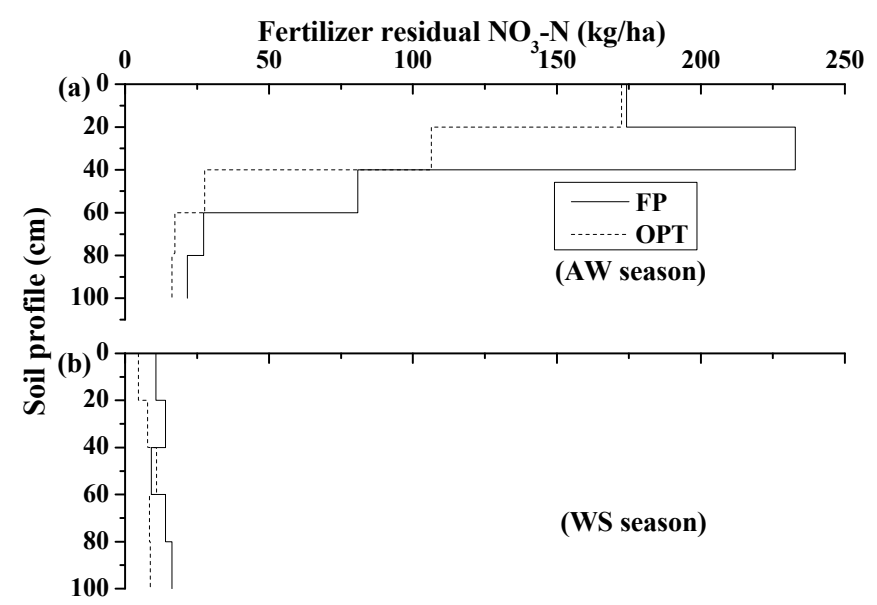

Figure 4. Distribution of ${ }^{15} \mathrm{~N}$-labeled urea $\mathrm{NO}_{3}{ }^{-} \mathrm{N}$ in the soil profile $(0-100 \mathrm{~cm})$ for different treatments Note. (a): AW season, (b): WS season. 


\subsection{Ammonia Volatilization Derived from ${ }^{15} \mathrm{~N}$-Labeled Urea}

The temporal variations in the ammonia volatilization derived from ${ }^{15} \mathrm{~N}$-labeled urea in the AW season are shown in Figure 5. A similar pattern in the FP and the OPT treatment showed that the ammonia volatilization fluxes reached maxima on the second day after each $\mathrm{N}$ fertilizer application in basal dressing, followed by a rapid decline. However, ammonia volatilization fluxes reached maxima on the third day after each $\mathrm{N}$ fertilizer application in top-dressing, followed by a rapid decline. Most of the ammonia volatilization occurred during the first $5 \mathrm{~d}$ after $\mathrm{N}$ fertilizer application.

The maximum fluxes were recorded at $0.4,0.3,0.2,0.2$ and $0.3 \mathrm{~N} \mathrm{~kg} /(\mathrm{ha} \cdot \mathrm{d})$ in the FP treatment after basal dressing and top-dressing, respectively. The significantly lower ammonia volatilization from the OPT treatment was largely due to the lower fertilizer $\mathrm{N}$ inputs during these periods (relative to the FP treatment) $(P<0.05)$. The total ${ }^{15} \mathrm{~N}$-labeled urea loss through ammonia volatilization from the FP treatment was $2.9 \mathrm{~N} \mathrm{~kg} /(\mathrm{ha} \cdot \mathrm{d}$ ) during the whole growing season, which accounted for $0.3 \%$ of total ${ }^{15} \mathrm{~N}$-labeled urea applied to the greenhouse vegetable field. The total ${ }^{15} \mathrm{~N}$-labeled urea loss through ammonia volatilization from the OPT treatment was $1.0 \mathrm{~N} \mathrm{~kg} /(\mathrm{ha} \cdot \mathrm{d})$ during the whole growing season, which accounted for $0.2 \%$ of total ${ }^{15} \mathrm{~N}$-labeled urea input into the greenhouse vegetable field. Because ammonia volatilization was small during the AW season, it was not measured in the WS season.

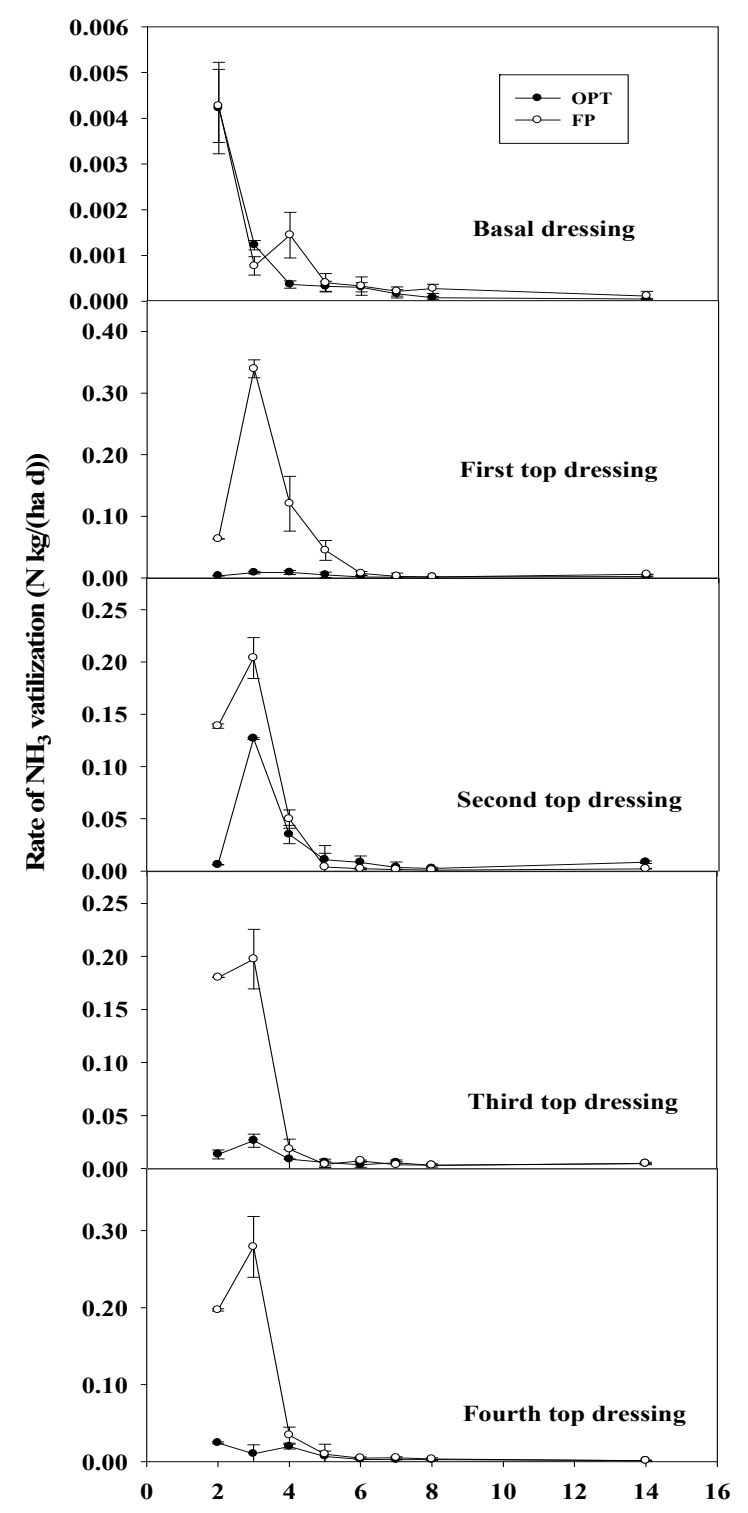

Figure 5. Effects of different $\mathrm{N}$ treatments on rate of ammonia volatilization 


\section{Discussion}

\subsection{Effect of Different $N$ Fertilizer Treatments on Recovery Efficiency of ${ }^{15} N$-Labeled Urea in the AW Season}

Our results showed that the majority of $\mathrm{N}$ fertilizer applied was not used by the tomato during the growing season. The recovery efficiency of ${ }^{15} \mathrm{~N}$-labeled urea by tomatoes was only $9.6 \%$ in the FP treatment, indicating that $90.4 \%$ of the $\mathrm{N}$ fertilizer applied was not recovered in the tomato (including fruit and shoot) during the AW season. Similar result was obtained by Han et al. (2010), which $<10 \%$ of the applied inorganic $\mathrm{N}$ fertilizer is actually used for vegetable production. It meant that the recovery of crop were extremely low and extremely inefficient, when a crop recovery was only $11 \%$ (Zhu et al., 2005).

The recoveries of $\mathrm{N}$ fertilizer by crops are prone to be highly variable, and are affected by different management practices. In the present study, OPT treatment improved the recovery efficiency of ${ }^{15} \mathrm{~N}$-labeled urea in tomato to $17.2 \%$ compared to $9.6 \%$ in the FP treatment in the AW season. Some reports also obtained similar results, for example, conventional $(2100 \mathrm{~kg} / \mathrm{ha})$ and optimum $\mathrm{N}$ treatment $(900 \mathrm{~kg} / \mathrm{ha})$ during cucumber growth in a greenhouse resulted in $\mathrm{N}$ recovery efficiencies of $4.9 \%$ and $10.6 \%$, respectively (Yang et al., 2013). Recovery efficiencies of $\mathrm{N}$ fertilizer were in the range of $5.1 \%-44.0 \%$ with use of different management practices in red soil in South China (Cai et al., 1995), implying that the fertilizer combination had significant effects on recoveries of $\mathrm{N}$ fertilizer. Drip irrigation with optimized $\mathrm{N}$ fertilization had a positive impact on increasing the $\mathrm{N}$ recovery efficiency, which may have been due to better water utilization, higher uptake of nutrients (Bafna et al., 1993; Hebbar et al., 2004) and excellent soil-water-air relationships with higher oxygen concentrations in the root zone (Gomat et al., 1973). Another possible reason was the combination of maize straw. Huo et al. (2005) reported that the combination of inorganic $\mathrm{N}$ and wheat residues improved $\mathrm{N}$ fertilizer use efficiency of summer maize, suggested that reasonable accommodating the application proportion of $\mathrm{C}$ and $\mathrm{N}$ nutrition in soil by application maize straw could increase residual rate of chemical $\mathrm{N}$ fertilizer in soil and advance $\mathrm{N}$ use efficiency of crop.

\subsection{The Residual Effect of ${ }^{15} N$-Labeled Urea on Subsequent Crops}

Despite a considerable amount of ${ }^{15} \mathrm{~N}$-labeled urea still remaining in the $0-100 \mathrm{~cm}$ soil profile, crop recovery of $\mathrm{N}$ fertilizer (applied as ${ }^{15} \mathrm{~N}$-labeled urea in the AW season) by the subsequent crop was $<5.0 \%$ of the initial amount applied. The recovery efficiency of ${ }^{15} \mathrm{~N}$-labeled urea by tomato in WS season was $1.7 \%$ and $3.5 \%$ in the FP and OPT treatments, respectively, equivalent to $17.7 \%$ and $20.3 \%$ of corresponding values in the AW season. As expected, most of the $\mathrm{N}$ fertilizer recoveries was in the AW season, and decreased in the subsequent growing season. This suggested that the re-utilization of residual $\mathrm{N}$ in the soil was very limited. Our results were in agreement with reports that the recovery of ${ }^{15} \mathrm{~N}$-labeled urea in millet was $3.0 \%$ for maize in a maize-millet rotation (Pilbeam et al., 2002), while the recovery of residual urea-ammonium nitrate- ${ }^{15} \mathrm{~N}$ in maize for three subsequent growing seasons in a continuous maize system were in the range of $1.7 \%-3.5 \%$ (Timmons \& Cruse, 1991). The low recovery of residual $\mathrm{N}$ by subsequent crops might be, in part, due to a large amount of fertilizer $\mathrm{N}$ preventing the use of $\mathrm{N}$ present naturally in soil. Residual $\mathrm{N}$ fertilizer was composed of ammonium, nitrate, soil microbe biomass and N-containing metabolites, with a considerable proportion of these being transformed into more stable soil pools (Jensen et al., 1997). Additionally, the content of $\mathrm{N}$ in irrigation water should not be overlooked. The $\mathrm{NO}_{3}{ }^{-}-\mathrm{N}$ concentrations of irrigation water were uniformly $>10 \mathrm{mg} / \mathrm{L}$, the acceptable standard level for drinking water. The average value of $\mathrm{NO}_{3}{ }^{-} \mathrm{N}$ concentration was $29.6 \mathrm{mg} / \mathrm{L}$. The $\mathrm{N}$ fertilizer of 120.4 $\mathrm{kg} / \mathrm{ha}$ was added to soil followed by irrigation water in the whole season. Compared with FP treatment, there was more residual uptake of ${ }^{15} \mathrm{~N}$-labeled urea by subsequent crops in the OPT treatment. Malhi et al. (2011) also suggested that the retention of straw combined with inorganic $\mathrm{N}$ fertilizer could increase $\mathrm{N}$ uptake efficiency by subsequent crops. Choi et al. (2004) found that the combined application of inorganic $\mathrm{N}$ and straw could result in $\mathrm{N}$ immobilization during early stages, and the nutrients may be released later when the nutrient demands of plants are higher (Herai et al., 2006).

\subsection{Accumulation and Loss of ${ }^{15} \mathrm{~N}$-Labeled Urea}

Of the applied ${ }^{15} \mathrm{~N}$-labeled urea, 580.0 and $372.8 \mathrm{~kg} \mathrm{~N} / \mathrm{ha}$ remained in the $0-100 \mathrm{~cm}$ soil profile at harvest in the AW season under the FP and OPT treatments, respectively. We found that the residual ${ }^{15} \mathrm{~N}$-labeled urea in soil was largely present as $\mathrm{NO}_{3}{ }^{-} \mathrm{N}$ and accounted for $92.5 \%$ and $91.3 \%$ in the FP and OPT treatments, respectively. This was in agreement with the result of Broadbent (1980), who suggested that residual $\mathrm{N}$ fertilizer mainly remained as inorganic $\mathrm{N}$ in the first season. The significantly $(P<0.05)$ higher $\mathrm{NO}_{3}{ }^{-} \mathrm{N}$ accumulated down to 40 $\mathrm{cm}$ in the FP (129.8 kg N/ha) compared to the OPT treatment with $61.4 \mathrm{~kg} \mathrm{~N} / \mathrm{ha}$, where it cannot be easily absorbed by the crop. In the WS season, $\mathrm{NO}_{3}^{-} \mathrm{-N}$ was also the dominant form of soil mineral $\mathrm{N}$ derived from ${ }^{15} \mathrm{~N}$-labeled urea in the FP treatment: $67.2 \% \mathrm{NO}_{3}^{-}-\mathrm{N}$ had accumulated in the $0-100 \mathrm{~cm}$ profile and $>50 \%$ of 
$\mathrm{NO}_{3}{ }^{-} \mathrm{-N}$ had accumulated down to $40 \mathrm{~cm}$. Large amounts of residual $\mathrm{NO}_{3}{ }^{-}-\mathrm{N}$ increase the risk of $\mathrm{N}$ loss to the groundwater. Lin et al. (2011) showed that $70 \%$ of deep groundwater has been polluted by $\mathrm{NO}_{3}{ }^{-}$in Shouguang, resulting from flood irrigation with excessive $\mathrm{N}$ application. Less $\mathrm{N}$ input could reduce $\mathrm{NO}_{3}{ }^{-}$leaching (Min et al., 2012). In the present study, $\mathrm{N}$ fertilizer applied in the OPT treatment was half of that in the FP treatment, and only $24.1 \% \mathrm{NO}_{3}{ }^{-}-\mathrm{N}$ had accumulated in the $0-100 \mathrm{~cm}$ soil profile. It has been demonstrated that inorganic ${ }^{15} \mathrm{~N}$ can be incorporated into the stable fraction of organic matter and has a positive effect on the reduction in $\mathrm{NO}_{3}{ }^{-}$ leaching (Ju et al., 2007; Kai et al., 1973). Generally, straw application increases soil organic matter content and soil buffer capacity (Luxhøi et al., 2007). Our result showed that soil C:N increased from 5.8 to 6.8 with straw incorporation, which might be useful in improving the soil environment for establishment of the microbial community. In addition, straw application was conductive to immobilize mineral $\mathrm{N}$ into the soil organic pool (Qiu et al., 2013). Thus, the reducing the conventional $\mathrm{N}$ fertilizer application by $50 \%$ and combining it with maize straw could significantly reduce the amount of $\mathrm{NO}_{3}^{-}-\mathrm{N}$ in greenhouse vegetable production.

High $\mathrm{N}$ losses occur with high rates of $\mathrm{N}$ application in greenhouse vegetables. In the present study, the loss rate of $\mathrm{N}$ derived from ${ }^{15} \mathrm{~N}$-labeled urea was $46.8 \%$ in the FP treatment, an increase of $25.8 \%$ compared with the OPT treatment. Similar conclusion was made by Zhu et al. (2005), who evaluated the season $\mathrm{N}$ balance in a hot pepper cropping system and found that $52.0 \%$ of $\mathrm{N}$ applied as fertilizer was lost from the soil-plant system. $\mathrm{N}$ losses also occurred via gaseous $\mathrm{N}$ emissions; and ammonia volatilization is an important pathway for $\mathrm{N}$ loss from agricultural fields, which results in a reduction in $\mathrm{N}$ recovery efficiency and increase environmental pollution (Zhou et al., 2009). Our data suggested that $\mathrm{N}$ lost through ammonia volatilization derived from ${ }^{15} \mathrm{~N}$-labeled urea only accounted for $0.9 \%$ and $2.4 \%$ of the total N lost in FP and OPT treatments, respectively. This result agreed with that of Zhu et al. (2005), who found negligible ammonia volatilization from a vegetable field in northern China. Compared with FP treatment, ammonia volatilization was significantly lower in the OPT treatment. One possible reason might be the reduced $\mathrm{N}$ fertilization combined with drip irrigation. Li (2010) suggested that during the cucumber growing season, ammonia volatilization decreased by $22.1 \%-37.2 \%$ under conditions of reduced irrigation water and $\mathrm{N}$ fertilizer. Returning maize straw to the field is another possible reason. Su et al. (2014) reported that returning maize straw to the field resulted in a significant reduction in ammonia volatilization compared to without returning. The reduction of ammonia volatilization loss might be ascribed to straw decreasing the soil $\mathrm{N}$ availability.

\section{Conclusions}

As a result of intensive greenhouse vegetable production in northern China, the potential risk of chemical $\mathrm{N}$ over-applied is increasing apparent and is threatening ecosystem and the sustainability of food production. Thus, providing optimal chemical $\mathrm{N}$ management method to improve chemical $\mathrm{N}$ use efficiency, reduce the risk of excessive chemical $\mathrm{N}$ application and enhance cultivated land productivity will have a crucial effect on the developments of greenhouse vegetable. The results obtained in the present study revealed that in the fertile soils used for greenhouse vegetable production, chemical $\mathrm{N}$ fertilizer application could be reduced from the conventional rate of 1000 to $500 \mathrm{~kg} \mathrm{~N} / \mathrm{ha}$ without loss of crop yields and significantly enhanced recovery efficiency of chemical $\mathrm{N}$ fertilizer and reduced chemical $\mathrm{N}$ losses to the environment, but should be combined with straw and drip irrigation. Considering the high chemical $\mathrm{N}$ use efficiency and the minimum environmental threat, we should fully take into account the optimization application by reducing chemical $\mathrm{N}$ inputs combined with adjustment of the $\mathrm{C} / \mathrm{N}$ ratio and water-fertilizer coupling. These combined approaches represent a practical means for reducing excess $\mathrm{N}$ input while maintaining the sustainability of greenhouse-based intensive vegetable systems.

\section{Acknowledgements}

We would like to thank the National Basic Research Program (973 program) of China (2013CB127406), National Nonprofit Institute Research Grant of CAAS (IARRP-2015-21), the International Scientific and Technological Cooperation Projects of China (S2015ZR1163), the Ministry of Agriculture Public Benefit Research Foundation of China (201103007), Special Fund of Research Institute Technology Development (2012EG134235) for their financial support.

\section{References}

Bafna, A. M., Daftardar, S. Y., Khade, K. K., Patel, V. V., \& Dhotre, R. S. (1993). Utilization of nitrogen and water by tomato under drip irrigation system. J. Water Manage., 1(1), 1-5.

Bao, S. D. (2000). Soil and Agricultural Chemistry Analysis (pp. 52-60). Beijing: China Agriculture Press.

Broadbent, F. E. (1980). Residual effects of labeled $\mathrm{N}$ in field trials. Agron. J., 72, 325-329. 
http://dx.doi.org/10.2134/agronj1980.00021962007200020018x

Bronson, K. F., Hussain, F., Pasuquinn, E., \& Ladha, J. K. (2000). Use of ${ }^{15} \mathrm{~N}$-labeled soil in measuring nitrogen fertilizer recovery efficiency in transplanted rice. Soil Sci. Soc. Am. J., 64, 235-239. http://dx.doi.org/10.2136/sssaj2000.641235x

Cai, G. X., Peng, G. H., Wu, Y. W., Ma, M. T., Gan, S. W., \& Men, C. F. (1995). Fate of urea nitrogen applied to rape grown on a red soil and efficiency of urea in raising rape yield. Pedosphere., 5, 107-114.

Chen, Q., Zhang, X. S., Zhang, H. Y., Christie, P., Li, X. L., Horlacher, D., \& Liebig, H. P. (2004). Evaluation of current fertilizer practice and soil fertility in vegetable production in the Beijing region. Nutr. Cycl. Agroecosyst., 69, 51-58. http://dx.doi.org/10.1023/B:FRES.0000025293.99199.ff

Choi, W. J., Ro, H. Y., \& Chang, S. X. (2004). Recovery of fertilizer-derived inorganic- ${ }^{15} \mathrm{~N}$ in a vegetable field soil as affected by application of an organic amendment. Plant Soil., 263, 191-201. http://dx.doi.org/10.1023/B:PLSO.0000047726.09394.d3

$\mathrm{Du}, \mathrm{L} . \mathrm{F}$. (2005). The nitrogen fertilizer use efficiency and soil quality variation of vegetable soil system in Yangse Delta area (PhD. Dissertation). Chinese Academy of Agricultural Sciences, Beijing.

Fan, Z. B., Lin, S., Zhang, X. M., Jiang, Z. M., Yang, K. C., Jian, D. D., ... Wang, J. G. (2014). Conventional flooding irrigation causes an overuse of nitrogen fertilizer and low nitrogen use efficiency in intensively used solar. Agr Water Manage., 144, 11-19. http://dx.doi.org/10.1016/J.AGWAT.2014.05.010

Gomat, B., Goldberg, D., Rimon, D., \& Asher Ben, J. (1973). The physiological effect of water quality and method of application on tomato, cucumber and pepper. J. Am. Soc. Horti. Sci., 98(2), 202-205.

Grandy, A. S., \& Robertson, G. P. (2007). Land-use intensity effects on soil organic carbon accumulation rates and mechanisms ecosystems. Ecosystems., 10, 58-73. http://10.1007/s1007/s10021-006-9010-y

Guo, S. R., Sun, J., Shu, S., Lu, X. M., Tian, J., \& Wang, J. W. (2012). Analysis of general situation, characteristics, existing problems and development trend of protected horticulture in China. China Vegetables., 18, 1-14.

Han, P. Y., Jiao, X. Y., Wang, L. G., Dong, E. W., \& Wang, J. S. (2010). Use efficiency and fate of applied nitrogen in long-term tomato districts of Taiyuan. Chinese Journal of Eco-Agriculture., 18(3), $482-485$. http://dx.doi.org/10.3724/SP.J.1011.2010.00482

He, F. F. (2006). Studies on optimizing nitrogen management and environmental implication in greenhouse tomato cropping system (Ph.D. Dissertation). China Agricultural University, Beijing.

Hebbar, S. S., Ramachandrappa, B. K., Nanjappa, H. V., \& Prabhakar, M. (2004). Studies on NPK drip fertigation in field grown tomato (Lycopersicon esculentum Mill.). Eur. J. Agron., 21, 117-127. http://dx.doi.org/10.1016/S1161-0301(03)00091-1

Herai, Y., Kouno, K., Hashimoto, M., \& Nagaoka, T. (2006). Relationships between microbial biomass nitrogen, nitrate leaching and nitrogen uptake by corn in a compost and chemical fertilizer-amended regosol. Soil Sci. Plant Nutr., 52, 186-194. http://dx.doi.org/10.1111/j.1747-0765.2006.00031.x

Huo, Z., Fu, J. F., \& Wang, P. (2005). Effects of application of $\mathrm{N}$ fertilizer and crop residues as manure on summer maize N recovery rate. Soils, 37, 202-204.

Jensen, L. S., Christensen, L., Mueller, T., \& Nielsen, N. E. (1997). Turnover of residual ${ }^{15}$ N-labelled fertilizer N in soil following harvest of oilseed rape (Brassica napus L,). Plant Soil, 190, $193-202$. http://dx.doi.org/10.1023/A:1004253611044

Jiang, H. M., Zhang J. F., Song X. Z., Liu, Z. H., Jiang, L. H., \& Yang, J. C. (2012). Responses of agronomic benefit and soil quality to better management of nitrogen fertilizer application in greenhouse vegetable land. Pedosphere., 22(5), 650-660. http://dx.doi.org/10.1016/S1002-0160(12)60050-2

Jiang, H. M., Zhang, J. F., Li, L. L., Li, S. S., Zhang, S. Q., Pan, P., ... Yang, J. C. (2013). Utiliaztion and fate of nitrogen in greenhouse vegetable under optimized nitrogen fertilization. Plant Nutrition and Fertilizer Science., 19(5), 1146-1154. http://dx.doi.org/10.11674/zwyf.2013.0514

Ju, X. T., Liu, X. J., \& Zhang, F. S. (2002). Dynamics of various nitrogen forms in soils and nitrogen utilization under application urea and different organic materials. J. China Agr. Univ., 7, 52-56. http://10.3321/j.issn:1007-4333.2002.03.010

Ju, X. T., Liu, X. J., Pan, J. R., \& Zhang, F. S. (2007). Fate of ${ }^{15}$ N-labelled urea under a winter wheat-summer 
maize rotation on the North China Plain. Pedosphere., $17,52-61$. http://dx.doi.org/10.1016/S1002-0160(07)60007-1

Kai, H., Ahmad, Z., \& Harada, T. (1973). Factors affecting immobilization and release of nitrogen in soil and chemical characteristics of the nitrogen newly immobilized. III. Transformation of the nitrogen immobilized in soil and its chemical characteristics. Soil Sci. Plant Nutr., 19, 275-286. http://dx.doi.org/10.1080/00380768.1973.10432597

Lei, B. K., Fan, M. S., Chen, Q., Six, J., \& Zhang, F. S. (2010). Conversion of wheat-maize to vegetable cropping systems changes soil organic matter characteristics. Soil Sci. Soc. Am. J., 74, 1320-1326. http://dx.doi.org/10.2136/sssaj2009.0222

Li, Y. K. (2010). Study on the nitrogen loss in the protected soil under different water and nitrogen conditions during cucumber growing season. Chinese Academy of Agricultural Sciences Dissertation.

Lin, S., Liu, M. J., \& Fan, Z. B. (2011). Water and nutrient integrated management in green-house vegetable. In J. G. Wang (Ed.), Management of Degraded Vegetable Soilin Greenhouse (pp. 209-226). China Agricultural University Press, Beijing.

Loveland, P., \& Webb, J. (2003). Is there a critical level of organic matter in the agricultural soils of temperate regions: A review. Soil Tillage Res., 70, 1-18. http://dx.doi.org/10.1016/S0167-1987(02)00139-3

Lu, R. K. (2000). Analytical Methods of Soil Agrochemistry. China Agricultural Science and Technology Press, Beijing

Luxhøi, J., Elsgaard, L., Thomsen, I. K., \& Jensen, L. S. (2007). Effects of long-term annual inputs of straw and organic manure on plant $\mathrm{N}$ uptake and soil N fluxes. Soil Use Manage., 23, 368-373. http://10.1111/j.1475-2743.2007.00126.x

Malhi, S. S., Johnston, A. M., Gill, K. S., \& Pennock, D. J. (2004). Landscape position effects on the recovery of ${ }^{15} \mathrm{~N}$-labelled urea applied to wheat on two soils in Saskatchewan, Canada. Nutr. Cycl. Agroecosys., 68, 85-93. http://dx.doi.org/10.1023/B:FRES.0000012238.02635.7e

Malhi, S. S., Nyborg, M., Solberg, E. D., Dyck, M. F., \& Puurveen, D. (2011). Improving crop yield and N uptake with long -term straw retention in two contrasting soil types. Field Crop Res., 124, $378-391$. http://dx.doi.org/10.1016/j.fcr.2011.07.009

Min, J., Zhang, H. L., \& Shi, W. M. (2012). Optimizing nitrogen input to reduce nitrate leaching loss in greenhouse vegetable production. Agric. Water Manage., 111, 53-59. http://dx.doi.org/10.1016/j.agwat.2012.05.003

Min, J., Zhao, X., Shi, W. M., Xing, G. X., \& Zhu, Z. L. (2011). Nitrogen balance and loss in a greenhouse vegetable system in southeastern China. Pedosphere., 21(4), 464-472. http://dx.doi.org/10.1016/S1002-0160(11)60148-3

Olsen, S. R., Cole, C. V., Watanabe, F. S., \& Dean, L. A. (1954). Estimation of available phosphorus in soils by extraction with sodium bicarbonate (No. 939). Circular of United States Department of Agriculture, USDA, Washington, D.C.

Pilbeam, C. J., Gregory, P. J., Tripathi, B. P., \& Munankarmy, R. C. (2002). Fate of nitrogen-15-labelled fertilizer applied to maizemillet cropping systems in the mid-hills of Nepal. Bio Fert Soils, 35, $27-34$. http://dx.doi.org/10.1007/s00374-001-0436-2

Pratt, P. F. (1951). Potassium removal from Iowa soils by greenhouse and laboratory procedures. Soil Sci., 72 , 107-118. http://dx.doi.org/10.1097/00010694-195108000-00003

Qiu, S. J., Ju, X. T., Ingwersen, J., Guo, Z. D., Stange, C. F., Bisharat, R., ... Zhang, F. S. (2013). Role of carbon substrates added in the transformationof surplus nitrate to organic nitrogen in a calcareous soil. Pedosphere., 23, 205-212. http://dx.doi.org/10.1016/s 1002-0160(13)60008-9

Schindler, F. V., \& Knighton, R. E. (1999). Fate of fertilizer nitrogen applied to corn as estimated by the isotopic and difference methods. Soil Sci. Am. J., 63, 1734-1740. http://dx.doi.org/10.2136/sssaj1999.6361734x

Song, H., Guo, J. H., Ren, T., Chen, Q., Li, B. G., \& Wang, J. G. (2012). Increase of soil pH in a solar greenhouse vegetable production system. Soil Sci. Soc. Am. J., 76, 2074-2082. http://dx.doi.org/10.2136/sssaj2011.0445

Song, X. Z. (2007). Effect of nitrate leaching on groundwater in protected vegetable fields (PhD. Dissertation). 
China Agricultural University.

Song, X. Z., Zhao, C. X., Wang, X. L., \& Li, J. (2009). Study of nitrate leaching and nitrogen fate under intensive vegetable production pattern in Northern China. C. R. Biol., 332, 385-392. http://dx.doi.org/10.1016/j.crvi.2008.11.005

Su, W., Lu, J. W., Wang, W. N., Li, X. K., Ren, T., \& Cong, R. (2014). Influence of rice straw mulching on seed yield and nitrogen use efficiency of winter oilseed rape (Brassica napus L.) in intensive rice-oilseed rape cropping system. Field Crop Res., 159, 53-61. http://dx.doi.org/10.1016/j.fcr.2014.01.007

Tanaskovik, V., Cukaliev, O., Romic, D., \& Ondrasek, G. (2011). The influence of drip fertigation on water use efficiency in tomato crop production. Agric. Conspec. Sci., 76, 57-63.

Timmons, D. R., \& Cruse, R. M. (1991). Residual nitrogen-15 recovery by corn as influenced by tillage and fertilization $\quad$ method. Agron $\quad$ J., $357-363$. http://dx.doi.org/10.2134/agronj1991.00021962008300020019x

Wang, Z. H., Liu, X. J., Ju, X. T., Zhang, F. S., \& Malhi, S. S. (2004). Ammonia volatilization loss from surface-broadcast urea: Comparison of vented- and closed-chamber methods and loss in winter wheat-summer maize rotation in North China Plain. Communications in Soil Science and Plant, 35(19-20), 2917-2939. http://dx.doi.org/10.1081/CSS-200036499

Xu, J. Z., Liao, L, X., Tan, J. Y., \& Shao, X. H. (2013). Ammonia volatilization in gemmiparous and early seedling stages from direct seeding rice fields with different nitrogen management strategies: A pots experiment. Soil Till Res., 126, 169-176. http://dx.doi.org/10.1016/j.still.2012.07.005

Yang, Z. P., Mei, X. R., Gao, F., Li, Y. Z., \& Guo, J. X. (2013). Effect of different nitrogen fertilizer types and application on temporal and spatial variation of soil nitrate-nitrogen at cucumber field. J. Environmental Protection., 4, 129-135. http://dx.doi.org/10.4236/jep.2013.41015

Zhang, Q. W., Yang, Z. L., Zhang, H., \& Yi, J. (2012). Recovery efficiency and loss of 15N-labelled urea in a rice-soil system in the upper reaches of the Yellow River basin. Agr Ecosyst Environ., 158, 118-126. http://dx.doi.org/10.1016/j.agee.2012.06.003

Zhou, S. L., Wu, Y. C., Wang, Z. M., Feng, H. Y., Lu, L. Q., \& Wang, R. Z. (2009). Recovery of residual fertilizer-nitrogen by wheat in a winter wheat-summer maize rotation in the North China Plain: A soil column study. Agron J., 101, 925-932. http://dx.doi.org/10.2134/agronj2008.0171

Zhu, J. H., Li, X. L., Christie, P., \& Li, J. L. (2005). Environmental implications of low nitrogen use efficiency in excessively fertilized hot pepper (Capsicum frutescens L.) cropping systems. Agr. Ecosys. Environ., 111, 70-80. http://dx.doi.org/10.1016/j.agee.2005.04.025

\section{Copyrights}

Copyright for this article is retained by the author(s), with first publication rights granted to the journal.

This is an open-access article distributed under the terms and conditions of the Creative Commons Attribution license (http://creativecommons.org/licenses/by/3.0/). 